\title{
PENGETAHUAN DAN PERILAKU MAHASISWI FAKULTAS KEDOKTERAN DAN FARMASI UNIVERSITAS CENDERAWASIH DALAM UPAYA PENCEGAHAN KANKER SERVIKS
}

\section{KNOWLEDGE AND BEHAVIOR OF FEMALE STUDENTS OF FACULTY OF MEDICINE AND PHARMACY UNIVERSITAS CENDERAWASIH IN PREVENTION EFFORTS OF CERVICAL CANCER}

\author{
Elsye Gunawan ${ }^{1}$, Gerson Andrew Warnares ${ }^{2}$ \\ ${ }^{1}$ Program Studi Farmasi, Jurusan Biologi, \\ Fakultas Matematika dan Ilmu Pengetahuan Alam, Universitas Cenderawasih \\ Kampus Uncen Waena, Jl. Perumnas III Waena-Jayapura Papua 99358 \\ ${ }^{2}$ Program Studi Kedokteran, Fakultas Kedokteran, Universitas Cenderawasih \\ Kampus Abepura, Jl. Raya Sentani, Jayapura, Papua 99358 \\ Email: elsye001@gmail.com (Elsye Gunawan)
}

\begin{abstract}
ABSTRAK
Studi yang dilakukan oleh Global Burden of Disease Cancer Collaboration menyebutkan sepanjang 2015, tercatat 17,5 juta kasus kanker di dunia, yang menyebabkan 8,7 juta kematian. Tujuan dari penelitian ini adalah mengetahui tingkat pengetahuan dan perilaku mahasiswi kedokteran dan farmasi Universitas Cenderawasih (Uncen) dalam upaya pencegahan kanker serviks. Penelitian ini merupakan penelitian noneksperimental yang dianalisis secara deskriptif. Desain penelitian adalah potong lintang dimana pengambilan data hanya dilakukan satu kali pada bulan Agustus 2017 dengan metode survei dan kuesioner sebagai instrument penelitian. Lokasi penelitian dilakukan di Fakultas Kedokteran dan Program Studi Farmasi Universitas Cenderawasih. Hasil yang diperoleh dari penelitian ini adalah total responden 359 mahasiswi, umur responden paling banyak berusia 22 tahun $(23,12 \%)$, belum menikah $98,89 \%$, responden berasal dari Jayapura, tinggal bersama orang tua, sering berdiskusi dengan keluarga terutama ibu tentang kesehatan reproduksi. Sebagian besar responden mendapatkan informasi pencegahan kanker serviks dari mata kuliah dosen yaitu 63,79\%, media elektronik 57,94\%, dan 55,99\% mendapatkan informasi dari media cetak. Kesimpulan penelitian ini adalah tingkat pengetahuan mahasiswi tentang kanker serviks, cara pencegahan kanker serviks, dan perilaku pencegahan kanker serviks mahasiswi Fakultas Kedokteran dan Program Studi Farmasi, Universitas Cenderawasih dinilai baik.
\end{abstract}

Kata kunci: pengetahuan, pencegahan, perilaku, kanker serviks, mahasiswi Universitas Cenderawasih.

\section{ABSTRACT}

The Study of Global Burden of Disease Cancer Collaboration reported, there were 17.5 million cancer cases worldwide and 8.7 million deaths in 2015. Aims of this research was 
to find out the knowledge level and behavior of the female students Faculty of Medicine and Pharmacy Uncen in prevention efforts of cervical cancer. This research is a nonexperimental research with descriptive analysis. Data was collected in August 2017 by survey method in a cross sectional design. Questionnaire was used as the research instrument. The research was conducted in the Faculty of Medicine and Study Program of Pharmacy Cenderawasih University. From the total of 359 female students, with age of 22 respondents (23.12\%), mostly were unmarried 98.89\%, from Jayapura, living with parents, often discussing with family, especially mother, and they talked about reproductive health. The most respondents get information about cervical cancer prevention from lecturer's courses (63.79\%), electronic media (57.94\%), and print media (55.99\%). It can be concluded that the level of knowledge about cervical cancer, cervical cancer prevention and cervical cancer prevention behaviour of female students of Faculty of Medicine and Study Program of Pharmacy Cenderawasih University is considered good.

Key words: knowledge, prevention, behaviour, cervical cancer, Universitas Cenderawasih student. 


\section{Pendahuluan}

Studi yang dilakukan Global Burden of Disease Cancer Collaboration menyebutkan sepanjang 2015 tercatat 17,5 juta kasus kanker di dunia, yang menyebabkan 8,7 juta kematian (Fitzmaurice, 2017). Kanker tertinggi di Indonesia pada perempuan adalah kanker payudara dan kanker leher rahim. Menurut Ferlay dkk. (2014), berdasarkan estimasi Globocan, International Agency for Research on Cancer (IARC), insiden kanker payudara sebesar 40 per 100.000 perempuan, kanker leher rahim 17 per 100.000 perempuan, kanker paru 26 per 100.000 laki-laki, dan kanker kolorektal 16 per 100.000 laki-laki. Berdasarkan data Sistem Informasi Rumah Sakit Tahun 2010, kasus rawat inap kanker payudara sebesar 12.014 kasus (28,7\%) dan kanker leher rahim 5.349 kasus (12,8\%). Kanker serviks (kanker leher rahim) merupakan tumor ganas yang tumbuh di dalam leher rahim atau serviks (bagian terendah dari rahim) yang menempel pada puncak vagina. Penyebab utama kanker leher rahim adalah infeksi Human Papilloma Virus (HPV). Infeksi virus HPV dapat menyerang siapa saja, mulai dari perempuan berusia 20 tahun sampai perempuan yang tidak lagi dalam usia produktif.

Dalam hal ini, mahasiswi yang termasuk kelompok usia remaja akhir adalah remaja yang berada pada jenjang pendidikan di perguruan tinggi dengan latar belakang keilmuan. Mahasiswi pada jenjang perguruan tinggi dengan latar belakang kesehatan merupakan salah satu penggerak tindakan preventif kanker serviks. Hal ini karena remaja perempuan dengan latar belakang kesehatan mendapatkan informasi dan edukasi lebih mendalam tentang kesehatan reproduksi khususnya kanker serviks sehingga ketika para remaja mengetahui permasalahan kesehatan reproduksi yang dialami, remaja tersebut dapat melakukan tindakan perawatan organ reproduksi, pencegahan penyakit, maupun pengobatan penyakit HPV.

$$
\text { Berdasarkan latar belakang }
$$
tersebut, perlu dilaksanakan penelitian mengenai aspek pengetahuan dan perilaku mahasiswi Fakultas Kedokteran dan Program Studi Farmasi Uncen dalam upaya pencegahan kanker serviks sehingga dapat menumbuhkan adanya kesadaran akan pentingnya upaya pencegahan kanker serviks. 


\section{Metode Penelitian}

Penelitian ini merupakan penelitian noneksperimental yang akan dianalisis secara deskriptif. Penelitian ini merupakan potong lintang (cross sectional) dimana pengambilan data hanya dilakukan satu kali. Penelitian ini dimulai pada bulan Juli 2017 dan pengumpulan data dimulai pada bulan Agustus 2017 dengan menggunakan metode survei dan kuesioner sebagai instrument penelitiannya.

Variabel yang diukur pada penelitian ini adalah aspek pengetahuan dan aspek perilaku mahasiswi Fakultas Kedokteran dan Farmasi. Populasi dikhususkan pada mahasiswi yang sedang menempuh pendidikan sarjana Fakultas Kedokteran dan Farmasi yang sesuai kriteria dalam penelitian. Kriteria inklusi mahasiswi S1 yaitu berusia 16-25 tahun, wanita. Pengambilan sampel dalam penelitian ini menggunakan metode nonprobability sampling. Sampel yang memenuhi persyaratan sebagai responden diminta kesediannya untuk mengisi kuesioner.

$$
\text { Data yang didapatkan }
$$

dikelompokkan sebagai berikut: berdasarkan karakteristik responden seperti: jenis kelamin, usia, status, dan daerah asal; berdasarkan gambaran pengetahuan tentang kanker leher rahim (serviks) dan skriningnya; evaluasi sikap dan perilaku terhadap skrining kanker leher rahim (serviks)

\section{Lokasi Penelitian}

Lokasi penelitian ini dilakukan di lingkungan Fakultas Kedokteran dan Program Studi Farmasi, Universitas Cenderawasih.

Jalannya Penelitian

Penelitian ini merupakan penelitian deskriptif analitik menggunakan pendekatan cross sectional untuk mengetahui pengetahuan dan perilaku mahasiswi Fakultas Kedokteran dan Program Studi Farmasi Universitas Cenderawasih terhadap pencegahan kanker serviks. Populasi data penelitian ini adalah Semua mahasiswi Fakultas Kedokteran dan Program Studi Farmasi. Teknik sampling adalah nonprobability sampling. Instrumen penelitian yang digunakan adalah kuesioner untuk menilai pengetahuan dan perilaku mahasiswi terhadap pencegahan kanker serviks. Analisis data dimulai dengan pengecekan isi kuesioner, editing, coding, entry, dan analisis data. Analisis data berupa analisis deskriptif. Data dianalisis secara univariat. Analisis 
univariat berupa distribusi frekuensi disajikan dalam bentuk tabel.

\section{Hasil dan Pembahasan}

Dari 365 kuesioner yang disebarkan pada mahasiswi Fakultas Kedokteran dan Prodi Farmasi, 359 kuesioner memenuhi kriteria dan 6 kuesioner tidak memenuhi kriteria karena tidak diisi dengan lengkap. Semua responden adalah perempuan.

\section{Karakteristik Responden}

Pada penelitian ini diambil sampel mahasiswi Fakultas Kedokteran dan Prodi Farmasi, Universitas Cenderawasih sebanyak 359 mahasiswi. Responden terdiri dari $100 \%$ responden perempuan.

Bertambahnya usia seseorang mempengaruhi bertambahnya pengetahuan termasuk pengetahuan kesehatan reproduksi yang bisa juga diperoleh dari pengalamannya. Dalam penelitian ini dapat diketahui umur responden terdiri dari 3,62\% berusia 17 tahun; $10,86 \%$ berusia 18 tahun; $11,70 \%$ berusia 19 tahun; 17,83\% berusia 20; 21,17\% berusia 21 tahun; $23,12 \%$ berusia 22 tahun; 8,91\% berusia 23 tahun; 1,11\% berusia 25 tahun, dan $1,67 \%$ berusia 25 tahun.
Mahasiswi yang memiliki status telah menikah sebanyak 4 orang dan 355 mahasiswi belum menikah. Daerah asal mahasiswi Fakultas Kedokteran dan Prodi Farmasi berasal dari Jayapura, Toraja, Serui, Jawa, Wamena, Biak, Sorong, Makassar, Nabire, Merauke, Timika, dan daerah di luar Jayapura.

Persoalan yang sering muncul di mahasiswa sering dikaitkan dengan kontrol orang tua. Salah satunya adalah dengan melihat apakah mahasiswa tersebut tinggal bersama orang tua atau tidak. Penelitian menunjukkan sebagian besar dari responden tinggal bersama orang tua $(42,62 \%)$, di tempat kos yaitu sebanyak 41,23\%, $15,60 \%$ tinggal di rumah saudara, dan $0,56 \%$ tinggal bersama teman.

Komunikasi dengan orang tua memegang peranan yang penting dalam pendidikan kesehatan reproduksi. Dalam penelitian ini, sebagian besar mahasiswi mendiskusikan kesehatan reproduksi dengan keluarganya, terutama kepada ibu sebesar 83,29\%. Teman juga memegang peranan yang cukup penting yaitu 59,61\%. 
Tabel 1. Karakteristik responden mahasiswi di Fakultas Kedokteran dan Prodi Farmasi tahun 2017

\begin{tabular}{|c|c|c|}
\hline No & Karakteristik Responden & n (\%) \\
\hline \multirow[t]{2}{*}{1} & Jenis kelamin & \\
\hline & Perempuan & $359(100)$ \\
\hline \multirow[t]{10}{*}{2} & Umur & \\
\hline & 17 tahun & $13(3,62)$ \\
\hline & 18 tahun & $39(10,86)$ \\
\hline & 19 tahun & $42(11,70)$ \\
\hline & 20 tahun & $64(17,83)$ \\
\hline & 21 tahun & $76(21,17)$ \\
\hline & 22 tahun & $83(23,12)$ \\
\hline & 23 tahun & $32(8,91)$ \\
\hline & 24 tahun & $4(1,11)$ \\
\hline & 25 tahun & $6(1,67)$ \\
\hline \multirow[t]{3}{*}{3} & Status & \\
\hline & Belum menikah & $355(98,89)$ \\
\hline & Sudah menikah & $4(1,11)$ \\
\hline \multirow[t]{28}{*}{4} & Daerah asal & \\
\hline & Jayapura & $43(11,98)$ \\
\hline & Toraja & $42(11,70)$ \\
\hline & Serui & $36(10,03)$ \\
\hline & Jawa & $32(8,91)$ \\
\hline & Wamena & $31(8,64)$ \\
\hline & Biak & $30(8,36)$ \\
\hline & Sorong & $21(5,85)$ \\
\hline & Makasar & $18(5,01)$ \\
\hline & Nabire & $15(4,18)$ \\
\hline & Merauke & $11(3,06)$ \\
\hline & Timika & $9(2,51)$ \\
\hline & Sumut & $9(2,51)$ \\
\hline & Manado & $7(1,95)$ \\
\hline & Maluku & $7(1,95)$ \\
\hline & Manokwari & $8(2,23)$ \\
\hline & NTT & $6(1,67)$ \\
\hline & Deiyai & $5(1,39)$ \\
\hline & Arso & $5(1,39)$ \\
\hline & Sarmi & $4(1,11)$ \\
\hline & Paniai & $3(0,84)$ \\
\hline & Mambramo & $3(0,84)$ \\
\hline & Fak-fak & $3(0,84)$ \\
\hline & Keerom & $2(0,56)$ \\
\hline & Madura & $2(0,56)$ \\
\hline & Genyem & $2(0,56)$ \\
\hline & Teluk wondama & $1(0,28)$ \\
\hline & Bali & $1(0,28)$ \\
\hline
\end{tabular}




\begin{tabular}{|c|c|c|}
\hline & Yalimo & $1(0,28)$ \\
\hline & Ayamaru & $1(0,28)$ \\
\hline & Tolikara & $1(0,28)$ \\
\hline \multirow[t]{5}{*}{5} & Tempat tinggal selama kuliah & \\
\hline & Rumah orang tua & $153(42,62)$ \\
\hline & Rumah saudara & $56(15,60)$ \\
\hline & Kos & $148(41,23)$ \\
\hline & Lain-lain & $2(0,56)$ \\
\hline \multirow[t]{5}{*}{6} & Diskusi dengan keluarga & \\
\hline & Pernah & $201(60)$ \\
\hline & Kadang-kadang & $109(30,36)$ \\
\hline & Sering & $33(9,19)$ \\
\hline & Tidak pernah & $16(4,46)$ \\
\hline \multirow[t]{5}{*}{7} & Sering diajak diskusi & \\
\hline & Bapak & $3(0,84)$ \\
\hline & $\mathrm{lbu}$ & $299(83,29)$ \\
\hline & Saudara sekandung & $42(11,70)$ \\
\hline & Lain-lain & $15(4,18)$ \\
\hline \multirow[t]{5}{*}{8} & Diskusi dengan teman & \\
\hline & Pernah & $214(59,61)$ \\
\hline & Kadang-kadang & $72(20,06)$ \\
\hline & Sering & $60(16,71)$ \\
\hline & Tidak pernah & $13(3,62)$ \\
\hline \multirow[t]{3}{*}{9} & Mengikuti kegiatan kemasyarakatan & \\
\hline & Ya & $36(10,03)$ \\
\hline & Tidak & $323(89,97)$ \\
\hline \multirow[t]{5}{*}{10} & Penyediaan sarana informasi & \\
\hline & Pernah & $141(39,28)$ \\
\hline & Kadang-kadang & $99(27,58)$ \\
\hline & Sering & $70(19,50)$ \\
\hline & Sangat susah & $49(13,65)$ \\
\hline \multirow[t]{4}{*}{11} & Merokok & \\
\hline & Ya & $11(3,06)$ \\
\hline & Tidak & $348(96,94)$ \\
\hline & Total & $359(100)$ \\
\hline
\end{tabular}

Informasi mengenai kesehatan reproduksi dapat diperoleh dari unit kegiatan mahasiswa yang terdapat di fakultas maupun universitas. Penelitian ini menunjukan $89,97 \%$ tidak mengikuti kegiatan mahasiswa, hanya $10,03 \%$ mahasiswa Fakultas Kedokteran dan Prodi Farmasi yang mengikuti kegiatan mahasiswa.

Lingkungan geografis dan besar kemampuan ekonomi dapat berpengaruh terhadap penyediaan 
serta kesempatan dalam memperoleh

informasi kesehatan reproduksi.

Penelitian ini menunjukan bahwa

$39,28 \%$ mahasiswi pernah memperoleh

informasi, $\quad 27,58 \% \quad$ kadang-kadang

menerima informasi, $19,50 \%$ sering

memperoleh informasi, dan 13,65\%

sangat susah memperoleh informasi terkait kesehatan reproduksi. Kebiasaan pada mahasiswa yang kurang baik seperti merokok dapat meningkatkan potensi terkena kanker leher rahim. Pada penelitian ini didapatkan 96,94\% mahasiswi tidak merokok dan 3,06\% mahasiswi merokok.

Tabel 2. Jumlah responden yang memperoleh informasi pencegahan kanker serviks

\begin{tabular}{llc}
\hline No & Sumber Informasi & $\mathbf{n}(\%)$ \\
\hline 1 & Kanker Serviks & \\
& Ya & $334(93,04)$ \\
& Tidak & $25(6,96)$ \\
\hline 2 & Vaksin Human Papilloma Virus \\
& Ya & $221(61,56)$ \\
& Tidak & $138(38,44)$ \\
\hline 3 & Pap Smear & \\
& Ya & $170(47,35)$ \\
& Tidak & $189(52,65)$ \\
& &
\end{tabular}

Tabel 2 menunjukkan bahwa responden yang sudah memperoleh informasi pencegahan kanker serviks pada tiap aspeknya yaitu sebanyak 93,04\% mengetahui informasi tentang kanker serviks; 61,56\% mengetahui informasi tentang vaksin Human Papilloma Virus; dan $47,35 \%$ mengetahui informasi tentang pap smear. Sebagian besar responden tidak mengetahui informasi tentang pap smear (52,65\%). Oleh karena itu, dapat disimpulkan bahwa informasi tentang kanker leher rahim yang diperoleh responden masih kurang menyeluruh (Safrina, 2016).

Tabel 3 menunjukkan bahwa sebagian besar responden mendapatkan informasi pencegahan kanker serviks dari mata kuliah $(63,79 \%)$. Media elektronik dan media cetak juga cukup memegang peranan 
penting dalam mendapatkan informasi pencegahan kanker serviks, hal ini dapat dilihat dari hasil penelitian yaitu 57,94\% mahasiswi mendapatkan informasi pencegahan kanker serviks dari media elektronik dan 55,99\% mendapatkan informasi dari media cetak. Lingkungan juga berpengaruh dalam mendapatkan informasi pencegahan kanker serviks, hasil penelitian menunjukkan bahwa
$55,15 \%$ mahasiswi mendapatkan informasi pencegahan kanker serviks dari orang tua, dan dari teman sebanyak 52,37\%. Sedangkan sumber yang terendah dalam mendapatkan informasi pencegahan kanker serviks adalah informasi dari guru 10,31\%, petugas kesehatan 6,41\%, seminar $3,06 \%$, dan organisasi lain yaitu 0,56\%.

Tabel 3. Sebaran sumber informasi pencegahan kanker leher rahim

\begin{tabular}{|c|c|c|}
\hline No & Sumber Informasi & n (\%) \\
\hline \multirow[t]{3}{*}{1} & Guru & \\
\hline & Ya & $37(10,31)$ \\
\hline & Tidak & $322(89,69)$ \\
\hline \multirow[t]{3}{*}{2} & Mata kuliah dan dosen & \\
\hline & Ya & $229(63,79)$ \\
\hline & Tidak & $130(36,21)$ \\
\hline \multirow[t]{3}{*}{3} & Orang tua & \\
\hline & Ya & $198(55,15)$ \\
\hline & Tidak & $161(44,85)$ \\
\hline \multirow[t]{3}{*}{4} & Teman & \\
\hline & Ya & $188(52,37)$ \\
\hline & Tidak & $171(47,63)$ \\
\hline \multirow[t]{3}{*}{5} & Media cetak & \\
\hline & Ya & $201(55,99)$ \\
\hline & Tidak & $158(44,01)$ \\
\hline \multirow[t]{3}{*}{6} & Media elektronik & \\
\hline & Ya & $208(57,94)$ \\
\hline & Tidak & $151(42,06)$ \\
\hline \multirow[t]{3}{*}{7} & Seminar atau pelatihan kesehatan reproduksi & \\
\hline & Ya & $11(3,06)$ \\
\hline & Tidak & $348(96,94)$ \\
\hline \multirow[t]{3}{*}{8} & Organisasi lain & \\
\hline & Ya & $2(0,56)$ \\
\hline & Tidak & $357(99,44)$ \\
\hline \multirow[t]{3}{*}{9} & Petugas Kesehatan & \\
\hline & Ya & $23(6,41)$ \\
\hline & Tidak & $336(93,59)$ \\
\hline
\end{tabular}


Tabel 4. Sebaran sumber informasi yang diharapkan berdasarkan urutan

\begin{tabular}{llc}
\hline No & \multicolumn{1}{c}{ Sumber } & $\mathbf{n}(\%)$ \\
\hline 1 & Mata kuliah dan dosen & $100(27,86)$ \\
2 & Petugas Kesehatan & $96(26,74)$ \\
3 & Media elektronik & $81(22,56)$ \\
4 & Seminar & $49(13,65)$ \\
5 & Media cetak & $19(5,29)$ \\
6 & Orangtua & $14(3,90)$ \\
7 & Guru sekolah & $0(0,0)$ \\
8 & Teman & $0(0,0)$ \\
9 & Organisasi & $0(0,0)$ \\
\hline & Total & $359(100)$ \\
\hline
\end{tabular}

Berdasarkan Tabel 4, mahasiswi

Fakultas Kedokteran dan Prodi Farmasi

Universitas Cenderawasih menilai sumber informasi yang terbaik adalah mata kuliah dan dosen. Hal tersebut sudah sesuai dengan sumber informasi terbanyak yang didapatkan oleh mahasiswi pada Tabel 3 dimana sumber informasi terbanyak adalah dari mata kuliah dan dosen.

Tingkat Pengetahuan Kanker Serviks

Berdasarkan Tabel 5 didapatkan

tingkat pengetahuan kanker serviks responden baik sebanyak 95,26\% dan kurang baik sebanyak 4,74\%. Pengetahuan mengenai pencegahan kanker serviks sangat diperlukan untuk dapat mengubah sikap dan perilaku wanita dalam menjaga kesehatan organ reproduksinya. Melalui pencegahan dan deteksi kanker serviks sedini mungkin, maka akan semakin besar kesempatan disembuhkannya penyakit ini dan semakin besar pula kemungkinan untuk menekan angka kejadian kasus kanker serviks pada wanita (Sari, 2010).

Tabel 5. Tingkat pengetahuan kanker serviks

\begin{tabular}{ccc}
\hline Tingkat pengetahuan & $\begin{array}{c}\text { Baik } \\
\mathbf{n}(\%)\end{array}$ & $\begin{array}{c}\text { Kurang } \\
\mathbf{n}(\%)\end{array}$ \\
\hline Tingkat pengetahuan kanker serviks & $342(95,26)$ & $17(4,74)$ \\
\hline
\end{tabular}


Penelitian ini sejalan dengan Delima dkk. (2016) dimana hasil yang didapatkan yaitu tingkat pengetahuan baik sebanyak 97,4\% dan tingkat pengetahuan kurang sebanyak 2,6\%. Penelitian serupa juga dilakukan oleh Komalasari (2012) dimana hasil yang diperoleh adalah tingkat pengetahuan pencegahan kanker leher rahim responden baik sebanyak $52 \%$ dan pengetahuan sedang sebanyak $48 \%$.

Menurut Meliono (2007), pengetahuan dipengaruhi oleh beberapa hal, yaitu pendidikan, media, dan keterpaparan informasi. Partisipan dalam penelitian ini adalah mahasiswi Universitas Cenderawasih yang sedang melanjutkan studi di perguruan tinggi. Ditinjau dari tingkat pendidikan, maka sangat wajar jika partisipan memiliki tingkat pengetahuan yang baik tentang kanker serviks.

Pengetahuan Tentang Cara Pencegahan Kanker Serviks

Berdasarkan Tabel 6 didapatkan bahwa tingkat pengetahuan tentang cara pencegahan kanker serviks responden baik sebanyak $98,89 \%$ dan kurang baik sebanyak $1,11 \%$.

Tabel 6. Pengetahuan tentang cara pencegahan kanker serviks

\begin{tabular}{ccc}
\hline Tingkat pengetahuan & Baik & Kurang \\
& $\mathbf{n ~ ( \% )}$ & $\mathbf{n ~ ( \% )}$ \\
\hline Pengetahuan tentang cara pencegahan kanker serviks & $355(98,89)$ & $4(1,11)$ \\
\hline
\end{tabular}

Perilaku Pencegahan Kanker Serviks

Berdasarkan hasil pada Tabel 7,

perilaku pencegahan kanker serviks responden baik sebanyak $97,49 \%$ dan kurang baik sebanyak 2,51\%. Hasil penelitian ini sejalan dengan penelitian yang dilakukan oleh Efrida (2013), yaitu sebanyak 62,9\% memiliki perilaku pencegahan kanker serviks yang baik.
Hasil dari penelitian yang dilakukan oleh Gustiana dkk. (2014) didapatkan mayoritas responden memiliki perilaku pencegahan baik terhadap kanker serviks sebanyak $63,6 \%$.

$$
\text { Notoatmodjo }
$$
mengatakan perilaku adalah suatu kegiatan atau aktivitas organisme atau makhluk hidup yang bersangkutan. 
Perilaku terbentuk di dalam diri seseorang dari dua faktor utama yaitu stimulus dan respon (Notoatmodjo, 2005). Dimana stimulus merupakan faktor dari luar diri seseorang (faktor eksternal), dan respon merupakan faktor dari dalam diri seseorang (faktor internal). Faktor eksternal dan internal inilah yang mempengaruhi seseorang untuk berperilaku terhadap pencegahan kanker serviks.

Tabel 7. Perilaku pencegahan kanker serviks

\begin{tabular}{ccc}
\hline Perilaku & $\begin{array}{c}\text { Baik } \\
\mathbf{n}(\%)\end{array}$ & $\begin{array}{c}\text { Kurang } \\
\mathbf{n}(\%)\end{array}$ \\
\hline Perilaku pencegahan kanker serviks & $350(97,49)$ & $9(2,51)$ \\
\hline
\end{tabular}

\section{Kesimpulan}

Kesimpulan penelitian ini adalah tingkat pengetahuan mahasiswi tentang kanker serviks, cara pencegahan kanker serviks, dan perilaku pencegahan kanker serviks mahasiswi Fakultas Kedokteran dan Prodi Farmasi, Universitas Cenderawasih dinilai baik.

\section{Daftar Pustaka}

Badan Penelitian dan Pengembangan. 2013. Riset Kesehatan Dasar. Jakarta: Kementerian Kesehatan RI.

Delima, N., Bahar, H., Erawan, P.E.M. 2016. Perilaku pencegahan kanker serviks pada mahasiswi Fakultas Kesehatan Masyarakat Universitas Halu Oleo Tahun 2016. Skripsi. Fakultas Kesehatan, Universitas Halu Oleo.
Efrida, M. 2013. Hubungan pengetahuan dan minat remaja putri dengan pencegahan kanker serviks di Madrasah Aliyah Negeri Darussalam Kabupaten Aceh Besar. http://stmikubudiyah.ac.id. Data diakses pada 04 Februari 2018.

Ferlay, J., Soerjomataram, I., Dikshit, R., Eser, S., Mathers, C., Rebelo, M., Parkin, D.M., Forman, D., Bray, F. 2014. Cancer incidence and mortality worldwide: sources, methods, and major pattern in GLOBOCAN 2012. International Journal of Cancer, 136(5):359-386.

Fitzmaurice, C. 2017. Global, regional, and national cancer incidence, mortality, years of life lost, years lived with disability, and disability-adjustedlife-years for 32 cancer groups, 1990 to 2015 : a systematic analysis for the global burden of disease study. JAMA Oncology, 3(4):524-548. 
Gustiana, D., Dewi, Y.I., Nurchayati, S. 2014. Faktor-faktor yang berhubungan dengan perilaku pencegahan kanker serviks pada wanita usia subur. JOM PSIK, 1(2):1-8.

Komalasari, K.W. 2012. Tingkat pengetahuan mahasiswa Fakultas Kedokteran Universitas Diponegoro angkatan 2011 terhadap pencegahan kanker leher rahim. Skripsi. Fakultas Kedokteran, Universitas Diponegoro.

Meliono, I. 2007. Pengetahuan - MPKT. Modul 1. Jakarta: Lembaga Penerbit FEUI.

Notoatmodjo, S. 2005. Promosi Kesehatan Teori dan Aplikasi. Jakarta: PT. Asdi Mahasatya.

Safrina, L., Sari, K., Mawarpury, M. 2016. Hubungan pengetahuan, sikap, dan perilaku wanita dewasa muda terhadap kanker leher rahim. Jurnal Mediapsi, 2(1):19-28.

Sari, L. 2012. Hubungan tingkat pengetahuan dengan perilaku pencegahan kanker serviks pada pasien di Klinik Seroja Kota Kediri. Jurnal Strada, 1(1):8591. 